\title{
Ihmiseen kohdistuvaa tutkimusta vastuullisesti
}

Tutkimuseettinen neuvottelukunta (TENK) on uudistanut ja ajanmukaistanut ihmiseen kohdistuvan, ei-lääketieteellisen tutkimuksen kansallinen ohjeen Ihmiseen kohdistuvan tutkimuksen eettiset periaatteet ja ibmistieteiden eettinen ennakkoarviointi Suomessa. Ohje toimii ihmistieteiden eettisten toimikuntien ennakkoarviointityön lähtökohtana. Tällainen yhteisesti sovittu kansallisen tason ennakkoarviointijärjestelmä on Euroopassa ainutlaatuinen.

Uudistuksessa on huomioitu uudistunut eurooppalainen tietosuojalainsäädäntö. Lisäksi eettisen ennakkoarvioinnin ohjeistusta on joiltakin osin hieman täsmennetty. Ohjeen soveltamisalaa on myös laajennettu koskemaan kaikkea ihmiseen kohdistuvaa, ei-lääketieteellistä tutkimusta. Ihmistieteiden eettiset periaatteet ja ennakkoarviointijärjestelmä ovat kuitenkin säilyneet pääosin ennallaan. TENK koordinoi ja valvoo ihmistieteen eettisten toimikuntien toimintaa.

\section{TENK VALVOO TIETEEN ITSESÄÄNTELYJÄRJESTELMÄÄ}

Tieteellinen tutkimus voi olla laadukasta vain, jos se on toteutettu eettisiä periaatteita ja hyvää tieteellistä käytäntöä noudattaen.

Suomessa tiedeyhteisö on sopinut yhdessä periaatteet ja säännöt, joita noudattamalla tutkimuksen tekeminen on vastuullista, rehellistä ja eettisesti kestävää. Ihmiseen kohdistuvan tutkimuksen eettiset periaatteet ovat osa tätä TENKin valvomaa itsesääntelyjärjestelmää.

Suomalaisen itsesääntelyjärjestelmän perustana on TENKin laatima ohje: Hyvä tieteellinen käytäntö ja sen loukkausepäilyjen käsitteleminen Suomessa, eli ns. HTK-ohje. HTK-ohje korostaa tutkimustyössä vaadittavaa rehellisyyttä. Sen tavoitteena on hyvän tieteellisen käytännön edistäminen ja tieteellisen epärehellisyyden ennaltaehkäiseminen.
Ihmistieteiden eettisiä periaatteita tuleekin lukea rinnan HTK-ohjeen kanssa. Molemmat ohjeet löytyvät TENKin sivuilta suomeksi, ruotsiksi ja englanniksi, HTK-ohje lisäksi vielä venäjäksi, kiinaksi ja espanjaksi: www.tenk.fi

\section{TUTKIMUSETIIKKA ON REHELLISYYTTÄ JA AMMATTITAITOA}

TENKin ohjeet on laadittu yhteistyössä suomalaisen tiedeyhteisön kanssa ja kaikki suomalaiset yliopistot, ammattikorkeakoulut ja muut keskeiset tutkimusorganisaatiot ovat allekirjoituksellaan sitoutuneet noudattamaan niitä. Ohjeiden vaikuttavuus perustuu tähän vapaaehtoiseen sitoutumiseen.

Tutkijan ammattitaito edellyttää kunkin tieteenalan menetelmien hallinnan lisäksi eettisesti kestävien toimintatapojen hallitsemista. Jos tutkimuksen eettisistä periaatteista livetään, ei uhkana ole vain tutkimuksen kohteen tai sen tulosten vaarantuminen. Myös tutkijan oma ura voi olla uhattuna. Suomessa eettisten periaatteiden noudattamatta jättäminen, esimerkiksi tarvittavan eettisen ennakkoarvioinnin ohittaminen, voi olla myös hyvän tieteellisen käytännön (HTK) loukkaus.

Sitoutuessaan TENKin ohjeisiin organisaatiot sitoutuvat noudattamaan hyvää tieteellistä käytäntöä kaikessa tutkimuksessa ja ihmistieteiden eettisiä periaatteita ihmiseen kohdistuvassa tutkimuksessa. Tämän lisäksi ne sitoutuvat noudattamaan ohjeissa linjattuja prosesseja sekä tiedevilppiepäilyjen tutkinnassa että ihmistieteiden eettisessä ennakkoarvioinnissa.

\section{LAAJA-ALAISESTI IHMISEEN JA INHIMILLISEEN TOIMINTAAN KOHDISTUVA OHJE}

Ihmistieteellinen tutkimus käsitetään uudistuneessa ohjeessa laaja-alaisesti ihmiseen ja inhimilliseen 
toimintaan kohdistuvana. Ohjetta sovelletaan humanististen alojen, kasvatustieteiden ja yhteiskuntatieteiden ohella kaikkeen sellaiseen tieteelliseen tutkimukseen, joka kohdistuu ihmiseen tai jossa käytetään ihmistieteiden tutkimusmenetelmiä. Tällaisia aloja ovat esimerkiksi ihmiseen kohdistuva luonnontieteellinen tai tekniikan alan tutkimus, taiteellinen tutkimus ja joissain tapauksissa myös ei-kajoavaan terveys- tai lääketieteelliseen tutkimus.

Ihmiseen kohdistuvassa tutkimuksessa eettiset kysymykset korostuvat tutkijan ja tutkittavan kohtaamisessa. Tutkimusalaa oleellisempaa on tutkimuksessa käytetyt menetelmät: aina kun tutkija on tutkimusvuorovaikutuksessa ihmisten kanssa, tulee hänen huomioida tutkimukseen osallistuvien ihmisten itsemääräämisoikeus, turvallisuus ja oikeudenmukainen kohtelu.

\section{MILLOIN TUTKIMUS PITÄÄ ARVIOIDA ENNAKKOON?}

Lain mukaan lääketieteellinen tutkimus arvioidaan aina ennakkoon. Tutkimuslain (Laki lääketieteellisestä tutkimuksesta: http://www.finlex.fi/fi/ laki/ajantasa/1999/19990488) mukaan tutkimuksesta on saatava riippumattoman eettisen toimikunnan myönteinen lausunto ennen kuin sen voi aloittaa.

Kun ihmistä tutkitaan muilla tavoin, esimerkiksi haastattelemalla, tarkkailemalla tai erilaisin koejärjestelyin, ei eettinen ennakkoarviointi ole aina välttämätöntä. TENKin ohjeiden mukaan ennakkoarviointi on kuitenkin tehtävä, jos tutkimukseen liittyy yksi tai useampi seuraavista tutkimusasetelmista:

1. Tutkimuksessa poiketaan tietoon perustuvasta suostumuksesta. Osallistuminen ei esimerkiksi ole vapaaehtoista tai tutkittaville ei anneta riittävästi tai oikeaa tietoa tutkimuksesta.

2. Tutkimuksessa puututaan tutkittavien fyysiseen koskemattomuuteen.

3. Tutkimus kohdistuu alle 15 -vuotiaisiin ilman huoltajan erillistä suostumusta tai informointia, jonka perusteella huoltajalla olisi mahdollisuus kieltää lasta osallistumasta tutkimukseen.

4. Tutkimuksessa tutkittaville esitetään poikkeuksellisen voimakkaita ärsykkeitä.

5. Tutkimuksessa on riski aiheuttaa tutkittaville tai heidän läheisilleen normaalin arkielämän rajat ylittävää henkistä haittaa.
6. Tutkimuksen toteuttaminen voi merkitä turvallisuusuhkaa tutkittaville tai tutkijalle tai heidän läheisilleen.

Tarvittaessa sovelletaan tarkempia alakohtaisia ohjeita. Jos tutkimuksessa erimerkiksi puututaan tutkittavien fyysiseen koskemattomuuteen, on tarkistettava, onko kyseessä lääketieteen tutkimuslain mukaan arvioitava tutkimus.

Suomessa lainsäädäntö tai TENKin ohjeet eivät edellytä eettisen toimikunnan arviointia tutkimuksiin, jotka perustuvat puhtaasti julkisiin ja julkistettuihin tietoihin, rekisteri- ja asiakirja-aineistoihin tai arkistoaineistoihin. Tällaisenkin aineiston kohdalla on oltava huolellinen esimerkiksi henkilötietoihin liittyvissä kysymyksissä ja pidettävä huoli, että esimerkiksi tutkimuksen julkaisusta ei asiayhteyden perusteella ole mahdollista tunnistaa henkilöitä.

\section{TARKENNUKSIA HENKILÖTIETOJEN KÄSITTELYYN}

Tietosuojalainsäädännön uudistuminen keväällä 2018 yhtenäisti tietosuojaan liittyviä käytäntöjä Euroopassa. Koska ihmiseen kohdistuvassa tutkimuksessa käsitellään usein henkilötietoja, joutuivat tutkijat Suomessakin tarkistamaan menettelytapoja liittyen henkilötietoihin. Uudistunut lainsäädäntö huomioitiin TENKin ohjetta uudistaessa, mutta TENKin ohjeita ei ole sellaisenaan tarkoitettu lain soveltamiseen. Käytännön ratkaisuissa on aina noudatettava voimassa olevaa lainsäädäntöä ja oman organisaation täsmällisempiä tietosuojaohjeita.

Henkilötietojen käsittelyn tulee olla suunnitelmallista, vastuullista ja lainmukaista. Aineiston käsittelyyn liittyvät riskit on huomioitava jo tutkimuksen suunnitteluvaiheessa. Vastuullisuus ja eettisyys on huomioitava koko tutkimuksen ja sen myötä syntyvän aineiston elinkaaren ajan. Esimerkiksi tutkimusta julkaistaessa tutkimukseen osallistuneiden henkilöllisyys yleensä suojataan, ellei heidän kanssaan ole sovittu toisin.

\section{TIETOON PERUSTUVA SUOSTUMUS JA ITSEMÄÄRÄÄMIS- OIKEUS OVAT KESKEISIÄ EETTISIÄ PERIAATTEITA}

Vapaaehtoinen, tietoon perustuva suostumus on keskeinen eettinen periaate kaikessa ihmiseen kohdistuvassa tutkimuksessa. Tutkimukseen osallistumisen on oltava aidosti vapaaehtoista. Erityisen tärkeää on huolehtia vapaaehtoisuuden periaatteesta, jos tutkimukseen osallistumisesta päättää 
joku muu kuin tutkittava itse. Tutkittavalle henkilölle ei esimerkiksi saa syntyä tunnetta osallistumisen pakollisuudesta ja tutkimuksen keskeyttämisen tai suostumuksen peruuttamisen on oltava yksinkertaista eikö sille tarvitse kertoa syytä.

Suostuessaan tutkimukseen ihmisen on ymmärrettävä, mihin he suostuvat ja kuinka heidän henkilötietojaan käsitellään. Tutkittavan informoimisessa on oltava huolellinen ja esimerkiksi lapsille asiat on ilmaistava eri tavalla kuin vaikkapa oman tieteenalan asiantuntijoille, jotta varmistetaan, että tutkittavat henkilöt ymmärtävät, mitä tutkimukseen osallistuminen konkreettisesti tarkoittaa.

\section{ALAIKÄISET TUTKIMUKSEN KOHTEENA JA OSALLISINA}

On tärkeää, että kaikki ihmisryhmät, myös lapset ja nuoret, saavat tutkimuksissa äänensä kuuluviin. YK:n yleissopimus lasten oikeuksista linjaa, että lapsen näkemykset on otettava huomioon ja että lapsella on oikeus ilmaista vapaasti mielipiteensä valitsemassaan muodossa (https://www.finlex.fi/fi/sopimukset/sopsteksti/1991/19910060/19910060_2).

Kun tutkimus kohdistuu alaikäisiin tai vajaakykyisiin henkilöihin, on tutkimuksen suunnitellessa oltava erityisen huolellinen. Eettisiä periaatteita noudatetaan aina ihmisiä tutkittaessa riippumatta siitä minkä ikäisiä he ovat. Alle 15 -vuotiaan osallistumisesta tutkimukseen päättää kuitenkin ensisijaisesti hänen huoltajansa. Suurille vastaajamäärille kohdennettavissa kyselytutkimuksissa tai kun lapsia havainnoidaan esimerkiksi koululuokassa ilman, että heistä kerätään tunnisteellista tietoa, riittää että huoltajia informoidaan tutkimuksesta. Vaikka tutkimukseen osallistuminen edellyttäisi huoltajan suostumusta, alaikäinen antaa suostumuksen osallistumiseen kuitenkin aina ensisijaisesti itse.

Samaa tarkkuutta on noudatettava, kun tutkitaan vajaakykyisiä ihmisiä. Kenen tahansa toimintakyky voi olla alentunut hetkellisesti sairauden tai esimerkiksi vanhuuden vuoksi. On tärkeää, että myös vajaakykyiset ihmiset voivat osallistua tutkimukseen eikä esimerkiksi korkea ikä rajoita oikeutta päättää tutkimukseen osallistumisesta. Myös vajaakykyinen henkilö antaa suostumuksen osallistua tutkimukseen itse, vaik$\mathrm{ka}$ osallistuminen edellyttäisi laillisen edustajan hyväksyntää.
Tutkijoiden on aina kunnioitettava alaikäisen tai vajaakykyisen ihmisen itsemääräämisoikeutta ja keskeytettävä tutkimus, jos se on tutkittavan henkilön edun tai tahdon vastaista.

\section{EETTINEN ENNAKKOARVIOINTI TUTKIJAN APUNA}

Joskus tutkimuksen aihe on sellainen, että eettisestä periaatteesta on jollain tavoin poikettava. Tällöin on punnittava ovatko tutkimukseen osallistumisesta koituvat haitat oikeassa suhteessa tutkimuksella tavoiteltavaan uuteen tietoon. Onko tutkimuksen oletettu hyöty niin arvokasta, että se oikeuttaa mahdollisen haitan? Onko riskien minimoimiseksi tehty kaikki mahdollinen?

Eettisen ennakkoarviointijärjestelmän tarkoitus on auttaa tutkijoita tunnistamaan tutkimusasetelmaan liittyvät eettiset haasteet ennen tutkimuksen aloittamista. Tavoitteena on kannustaa tutkijaa pohtimaan keinoja tutkimuksesta mahdollisesti koituvien haittojen ja vahinkojen minimoimiseksi.

Arviointi on nimensä mukaisesti tehtävä ennakkoon eikä sitä saa enää jälkikäteen. Tämä on hyvä pitää mielessä, sillä usein kansainväliset lehdet, rahoittajat tai tutkimuskumppanit vaativat eettistä ennakkoarviointia myös sellaisille tutkimusasetelmille, jotka eivät suomalaisen järjestelmän mukaan tarvitse sitä.

Yleensä arvioinnin tekee tutkijan oman organisaation ihmistieteiden eettinen toimikunta. Toimikunta voi olla myös erillinen, tiettyyn tutkimusalaan liittyvä tai useamman organisaation yhteinen.

\section{KENEN VASTUULLA ON TUTKIMUKSEN EETTISYYS?}

TENKin ohjeisiin sitoutuneen organisaation vastuulla on työnantajana huolehtia siitä, että sen tiedeyhteisöön kuuluvat tutkijat, opettajat ja muu henkilökunta tuntevat tutkimusetiikkaan ja eettiseen ennakkoarviointiin liittyvät ohjeet ja suositukset ja että he noudattavat niitä. Tutkijan vastuulla on tieteenalasta riippumatta huolehtia, että tutkimuksen eettiset riskit ja suunnitellut toimintatavat haittojen ja vahinkojen välttämiseksi käsitellään jo tutkimussuunnitelmassa. Eettinen ennakkoarviointi ei koskaan siirrä vastuuta tutkijalta eettiselle toimikunnalle.

Luottamus tieteeseen säilyy vain, jos tutkimukseen osallistuvien ihmisten ihmisarvoa ja oikeuksia kunnioitetaan. Tieteellinen tutkimus 
on luotettavaa, jos tutkimuksessa on noudatettu hyvää tieteellistä käytäntöä. Eettinen ennakkoarviointijärjestelmä on yksi tapa varmistaa tutkimuksen kohteena olevien ihmisten turvallisuus. Samalla se helpottaa tutkijan omaa pohdintaa eettisesti haastavien tilanteiden edessä.

\section{IINA KOHONEN}

\section{TaT, asiantuntija}

Tutkimuseettinen neuvottelukunta

\section{LÄHTEET}

Hyvä tieteellinen käytäntö ja sen loukkausepäilyjen käsitteleminen Suomessa. Tutkimuseettisen neuvottelukunnan ohje 2012 (PDF) - ns. HTK-ohje - suomeksi, ruotsiksi ja englanniksi

Ihmiseen kohdistuvan tutkimuksen eettiset periaatteet ja ihmistieteiden eettinen ennakkoarviointi Suomessa. Tutkimuseettisen neuvottelukunnan ohje 2019

(PDF) (Tutkimuseettisen neuvottelukunnan julkaisuja 3/2019)
Laki lääketieteellisestä tutkimuksesta:

http://www.finlex.fi/fi/laki/ajantasa/1999/19990488

YK:n yleissopimus lasten oikeuksista:

https://www.finlex.fi/fi/sopimukset/

sopsteksti/1991/19910060/19910060_2

\section{LISÄÄ AIHEESTA}

Konttinen Outi 2018: Lääketieteen alan tutkimusetiikasta Suomessa. Vastuullinen tiede -verkkojulkaisu https://vastuullinentiede.fi/fi/tutkimuksen-suunnittelu/ laaketieteen-alan-tutkimusetiikasta-suomessa tarkistettu 3.7.2020

Oikari, Raija 2020: Ihmistieteiden eettistä ennakkoarviointia Suomessa vuodesta 2009. Vastuullinen tiede -verkkojulkaisu https://vastuullinentiede.fi/ fi/tutkimuksen-suunnittelu/ihmistieteiden-eettistaennakkoarviointia-suomessa-vuodesta-2009 tarkistettu 3.7.2020

Pekkarinen, Elina 2018: Kuka suostuu lasten ja nuorten tutkimuksessa? Vastuullinen tiede -verkkojulkaisu https://vastuullinentiede.fi/f/tutkimuksensuunnittelu/kuka-suostuu-lasten-ja-nuortentutkimuksessa tarkistettu 3.7.2020 